\title{
Causality test between exchange rate, inflation rate and Stock Price Index in Southeast Asia
}

\author{
Tifa Noer Amelia* \\ Perbanas Institute, Indonesia
}

\author{
Keywords: \\ Stock price index \\ Exchange rate \\ Inflation \\ Economic indicator
}

Received: 10 March 2016

Accepted: 16 March 2016

Published: 26 April 2016

\begin{abstract}
This paper examines the causality relationship between stock price index, exchange rate and inflation. The sample is gathered from monthly report for the period of 2012-2015 published in Southeast Asia consisting of Lao PDR, Malaysia, Indonesia, Singapore and Thailand. Hypothesis is found that all of the variables identified have a causality relationship. Research proves that the Southeast Asian countries should monitor each other's Economic condition continuously since a change in a country's indicator can relate and has the impact on the other country. However, the relationship strength is moderate and weak. So the research must be updated every year since it is valid for short term or maximum for one year.
\end{abstract}

(c) 2016 The Author(s). Published by TAF Publishing.

\section{INTRODUCTION}

Association of Southeast Nations (ASEAN) was established in 1867 to gather the nations under Southeast Asia region that consists of ten countries. They are Brunei Darussalam, Cambodia, Indonesia, Lao PDR, Malaysia, Myanmar, Philippines, Singapore, Thailand, and Vietnam (Secretariat, 2014). Southeast Asian Nation's territory is $4.494 .733 \mathrm{~km} 2$ with of population around 629.709.024 people (Organik, 2015). With this number, Southeast Asia's countries have numerous development efforts such as APEC (Asia Pacific Economic Co-operation), AFTA (ASEAN Free Trade Area), SAARC (South Asia Association for Regional Cooperation), GMS (Greater Mekong Sub-region, SCGT (Southern China Growth Triangle), and SIJORI GT (Singapore Johor Riau Growth Triangle). Southeast Asia's Gross Domestic Product (GDP) is 2.4 Billion U.S. dollar and predicted to

*Corresponding author: Tifa Noer Amelia

E-mail: ifanoer@gmail.com reach 5 Billion U.S. dollar in 2020, 45\% contribution on its sea lanes to the world. Stock price index, Exchange rate and Inflation are the most common Economic indicators that can be examined with any study background not only from Economic and Finance. These indicator are strong enough to affect the Economic condition in many countries. This is why a research in this area is important to examine.

\section{LITERATURE REVIEW}

There are previous researches that become the research base. The supportive research is described how inflation has an adverse effect on unemployment and poverty (Chakravarty \& Mitra, 2010). These economic indicators also played role in Economic and Financial crisis in Nigeria and South Africa affected by the spread between long and short term interest rates, lending and deposit rates, foreign trade, and hedging strategies (Ikoku \& Okany, 2014). In Pakistan, Inflation has a positively strong influence to 
Stock price Index (Ahmeda, \& Mubarikb, 2012). On the other hand, there is negative behavior of the inflation and exchange rate to stock exchange in Bovespa (da Silva, Coronel, \& Vieira, 2014). Intraregional linkages are not the only factor that improves Economic growth, there are social and political factor as well (Singh, 2015). The other cases are the fluctuation in gold price that is due to inflation, exchange rate, and stock price index (Ismail, Yahya, \& Shabri, 2009). Dynamic fluctuation in dollar countries also has the impact on economic growth so the inflation persistence is similar between dollarized and non-dollarized countries that spend more time away from their equilibrium level on the real exchange rate (Caputo \& Magendzo, 2011). Abandoning a pegged in exchange rate may be interpreted by some financial markets as signaling a less strong counter inflationary commitment by the government in Southeast Asian region (Bird \& Rajan, 2002). The last is the evidence that all the ten countries in Southeast Asia have strong Economic development ration, around 5.6\% unless they do not make domestic and external risk prevention. So that, continuous reformation, regional integration and strengthening institution's capacity (Taw, 2015) can be ensured.

\section{Hypothesis}

The research will examine these six hypotheses. A study developed the hypothesis that there is a link between the foreign exchange and stock markets. This link is positive when stock prices are the lead variable and likely negative when exchange rates are the lead variable (Dimitrova, 2005).

H1: Exchange Rate has positive causality relationship to Stock Price index.

H2: Stock Price index has positive causality relationship to Exchange Rate.

H3: Inflation Rate has positive causality relationship to Stock Price Index.

H4: Stock Price Index has positive causality relationship to Inflation Rate.

H5: Exchange rate has positive causality relationship to Inflation rate.

H6: Inflation rate has positive causality relationship to Exchange Rate.

\section{METHODOLOGY}

\section{Sample}

Indonesia, Singapore, Malaysia, Thailand, and Lao PDR are considered as having the largest economic growth in Southeast Asia (Geiger, 2014).

\section{Data Collection}

Data were gathered from five countries that represent South East Asia taken from several web sites, especially from the stock exchange, central bank and finance website such as Bloomberg and Yahoo Finance. At the beginning, the countries that will be examined consisted of all the countries that were geographically listed in ASEAN (Association of Southeast Asian Nations). Those countries are Brunei Darussalam, Indonesia, Cambodia, Lao PDR, Malaysia, Myanmar, Philippines, Singapore, Thailand, and Vietnam. But then, because of data availability and access limitation, this research can examine five countries, with the range of monthly data from 2012-2015. They are:

1. Stock Price Index

Stock is an asset of ownership of a company in the form of financial instrument. The value of fluctuation of stock price will be determined by the company's reputation, supply and demand of the stock. All listed companies will be the component of Stock price Index. In a stock exchange, broker can make a bid for the stock price offered. The stock price ups and downs are affected by internal and external factors. Internal factor will relate to the management ability to manage their business and finance and make a massive gain, sometimes in the form of revenue. External factor is mostly related to the economics condition in a country. To make of sure the stock price, stockbrokers can visit the Stock Exchange in every country (Idx, 2004). Stock price index information was gathered from the stock exchange web site in involved countries. Such as, idx.co.id for Indonesia, bursamalaysia.com for Malaysia, sgx.com for Singapore, set.or.th for Thailand, and lsx.com for Lao PDR.

2. Exchange Rate

Definition of exchange rate is to define a country's currency in term of foreign currency (Bank Indonesia (BI), 2013). This information was also gathered from the central bank in each country. Such as bingo for Indonesia, bnm.gov.my for Malaysia, mas.gov.sg for Singapore, bot.or.th for Thailand, and bol.gov.la for Lao PDR.

3. Inflation

Inflation is one of the effects of the prolonged economic crisis that is faced by a country. Inflation is a condition where there is an increase in price that is quite sharp (absolute), which takes place continuously in quite a long time, followed by further decline in the real value (intrinsic) of the currency of a country (Khalwaty, 2000). Inflation data from the involved countries were 
gathered from finance.yahoo.com.

\section{Model}

The research model will define the path of the hypothesis.

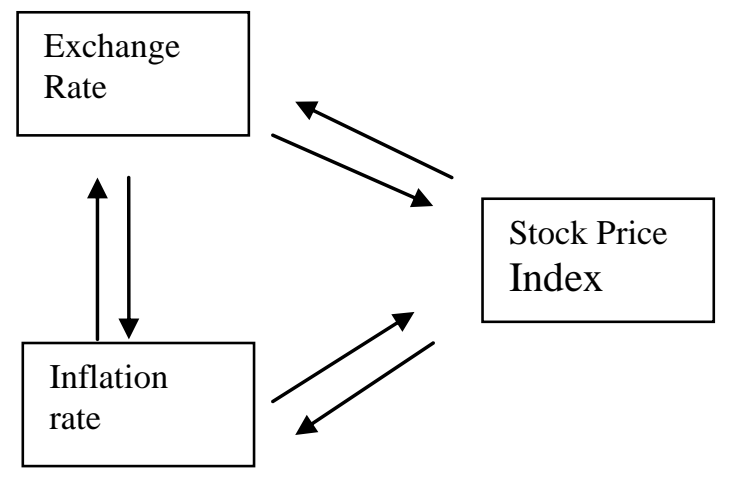

\section{Research Method}

This research is using quantitative Time-Series method. So the data will be examined by using EViews program. E Views (acronym: Econometric Views) is a Windows-based computer program that is widely used for statistical analysis and econometric kind of time-series (time series). The software was developed by Quantitative Micro Software (QMS) in 1994, that in 2007 has released version 6.0 (Wikipedia, 2013).

\section{Statistical Description}

Descriptive statistics is a field of statistical science that studies the ways of collecting, preparing, and presenting research data. Activities included in the category are activities of collecting or gathering the data, or grouping of data, the determination of value and statistical functions, including graphic and image creation (Ghozali, 2005). In this part we will generate several term related to the research such as Mean, Median, Maximum, standard deviation, skewness and Jarque-Bera

2. Unit Root Test

This part of the test will provide the information about the type of the test, exogenous variable, the lag length used, test output and associated critical value that is indicated with probability value. Augmented Dickey Fuller (ADF) test equation will determine whether the data is stationary or no by comparing the statistical value of $A D F$ with the critical value. If the $A D F$ value is higher than the critical value, the data is stationary. When the data is not stationary, persistence of shocks data will be infinite for no stationary series, the unrelated data possibly has a high R-Square, and the data validity is low.
3. Johansen Co integration Test

Johansen Co Integration test will explain about the length of the variables relationship, whether it's long or short-term. This approach uses maximum likelihood procedures that test for the number of co integration relationships. The availability of Co integration is based on likelihood ratio (LR) test. If the statistical value of LR is higher than the critical value then the co integration is acceptable.

4. Causality Test

Causality test is not just the relation between the variables but more to see how much of the current variable value can explain the past value of the variable and how they predict each other.

5. Vector Auto Regression (VAR)

The VAR approach is needed for structural modeling of the endogenous variable in the system as a function of the lagged values of the variable. Here we will read the $\mathrm{R}$ Square for the relation strength. R-Square shows the strength of the Stock Price Index explaining Exchange rate and Inflation in each country. Analysis of Respondents

\section{RESULTS}

\section{Unit Root Test}

Augmented Dickey Fuller (ADF) test statistic will be comparing between t-statistic with $5 \%$ critical value to the probability score.

TABLE 1. ADF test statistic of exchange rate

\begin{tabular}{cccccc}
\hline Lao LDR & Malaysia & Indonesia & Sing. & Thailan \\
\hline & & & & & \\
& & & & & \\
-3.5403 & -3.5442 & -3.5442 & -3.5403 & -3.5403 \\
\cline { 4 - 5 } & & & & & \\
\cline { 4 - 5 } & 0.0098 & 0.7362 & 0.3074 & 0.6115 & 0.4272 \\
& -3.5529 & -3.5403 & -3.5442 & -3.5403 & -3.5442 \\
B & 0.7315 & 0.8311 & 0.3074 & 0.0462 & 0.8932 \\
\hline
\end{tabular}

*A: Exchange rate; B: Inflation, above: t-stat, below: prob

ADF Test Statistic of Exchange rate 0.0098 is higher than the $5 \%$ critical value of -3.5403 . ADF Test Statistic of Inflation rate 0.7315 is higher than the $5 \%$ critical value of -3.5529. Data in Lao PDR is stationary. ADF Test Statistic of Exchange rate 0.7362 is higher than the $5 \%$ critical value of -3.5442. ADF Test Statistic of Inflation rate 0.8311 is higher than the $5 \%$ critical value of -3.5403 . Data in 
Malaysia is stationary. ADF Test Statistic of Exchange rate 0.3074 is higher than the $5 \%$ critical value of -3.5442 . ADF Test Statistic of Inflation rate 0.3817 is higher than the $5 \%$ critical value of -3.5442. Data in Indonesia is stationary. ADF Test Statistic of Exchange rate 0.6115 is higher than the $5 \%$ critical value of -3.5403 . ADF Test Statistic of Inflation rate 0.0462 is higher than the $5 \%$ critical value of -3.5403. Data in Singapore is stationary. ADF Test Statistic of Exchange rate 0.4272 is higher than the $5 \%$ critical value of -3.5403. ADF Test Statistic of Inflation rate 0.8932 is higher than the $5 \%$ critical value of -3.5442 . Data in Thailand is stationary.

TABLE 2. Johansen Co-integration test

\begin{tabular}{llll}
\hline \hline & Max-Eigen & $\mathbf{0 . 0 5}$ & \\
\hline Eigenvalue & Statistic & Critical Value & Prob.** \\
Lao PDR & & & \\
0.273481 & 11.18218 & 21.13162 & 0.6291 \\
$\begin{array}{c}\text { Malaysia } \\
0.280367\end{array}$ & 11.51546 & 21.13162 & 0.5959 \\
Indonesia & & & \\
0.209774 & 8.240274 & 21.13162 & 0.8884 \\
$\begin{array}{c}\text { Singapore } \\
0.313744\end{array}$ & 13.17768 & 21.13162 & 0.4360 \\
$\begin{array}{c}\text { Thailand } \\
0.451010\end{array}$ & 20.98864 & 21.13162 & 0.0523 \\
\hline \hline
\end{tabular}

TABLE 3. Granger causality test

\begin{tabular}{ll}
\hline Null Hypothesis: & Prob. \\
\hline X1A does not Granger Cause Y2 & 0.8827 \\
Y4 does not Granger Cause X1A & 0.0567 \\
X4B does not Granger Cause X1B & 0.0929 \\
X1B does not Granger Cause X4B & 0.0737 \\
X1B does not Granger Cause X5A & 0.0507 \\
Y2 does not Granger Cause X1B & 0.0746 \\
X2B does not Granger Cause X2A & 0.0597 \\
X3B does not Granger Cause X2A & 0.0691 \\
X2A does not Granger Cause X4A & 0.9724 \\
Y4 does not Granger Cause X2A & 0.0676 \\
X2B does not Granger Cause X3A & 0.0705 \\
X2B does not Granger Cause X4A & 0.0332 \\
X2B does not Granger Cause X4B & 0.0843 \\
Y2 does not Granger Cause X2B & 0.0549 \\
X4B does not Granger Cause X4A & 0.0653 \\
Y1 does not Granger Cause X4A & 0.0997 \\
X4B does not Granger Cause Y1 & 0.9748 \\
Y4 does not Granger Cause X5A & 0.0948 \\
\hline \hline
\end{tabular}

\begin{tabular}{ll}
\hline \hline Y1 does not Granger Cause X5B & 0.0936 \\
Y3 does not Granger Cause Y1 & 0.0913 \\
Y4 does not Granger Cause Y1 & 0.0619 \\
Y3 does not Granger Cause Y4 & 0.0725 \\
\hline
\end{tabular}

The critical value score is 0.6291 higher than the critical value of $5 \%$, so the relationship in Laos PDR is in the short run. The probability value is 0.5959 higher than the critical value of $5 \%$, so the relationship in Malaysia is in the short run. The probability value is 0.8884 higher than the critical value of $5 \%$, so the relationship in Indonesia is in the short run. The probability value is 0.4360 higher than the critical value of 5\%, so the relationship in Singapore is in the short run. The probability value is 0.0523 higher than the critical value of $5 \%$, so the relationship in Thailand is in the short run. This research is symbolized by the use of Y1 as Stock Price Index in Lao PDR, Y2 as Stock Price Index in Malaysia, Y3 as Stock Price Index in Indonesia, Y4 as Stock Price Index in Singapore and Y5 as Stock Price Index in Thailand. Inflation is symbolized by XA1 as Inflation in Lao PDR, XA2 as Inflation in Malaysia, XA3 as Inflation in Indonesia, XA4 as Inflation in Singapore and XA5 as Inflation in Thailand. Exchange rate is symbolized as XB1 as Exchange Rate in Lao PDR, XB2 as Exchange Rate in Malaysia, XB3 as Exchange Rate in Indonesia, XB4 as Exchange Rate in Singapore and XB5 as Exchange Rate in Thailand. From the results above, this research found that Exchange Rate in Lao PDR positively has causality relationship with Stock Price Index in Malaysia. Stock Price Index in Singapore positively has causality relationship with Exchange Rate in Lao PDR. Inflation in Singapore positively has causality relationship to Inflation in Lao PDR. Inflation in Lao PDR positively has causality relationship with Inflation in Singapore. Inflation in Lao PDR positively has causality relationship with Exchange rate in Thailand. Stock Price Index in Malaysia positively has causality relationship with Inflation in Lao PDR.

Inflation in Malaysia positively has causality relationship with Exchange rate in Malaysia. Inflation in Indonesia positively has causality relationship with Exchange rate in Malaysia. Exchange rate in Malaysia positively has causality relationship with Exchange rate in Singapore. Stock price index in Singapore positively has causality relationship with Exchange rate in Malaysia. Inflation in Malaysia positively has causality relationship with Exchange rate in Indonesia. Inflation in Malaysia positively has causality relationship to Exchange rate in Singapore. Inflation in Malaysia positively has causality 
relationship with inflation in Singapore. Stock price index in Malaysia positively has causality relationship with inflation in Malaysia. Inflation in Singapore positively has causality relationship with Exchange rate in Singapore.

TABLE 4. Vector auto regression

\begin{tabular}{lllllll}
\hline \hline Finding & Lao PDR & \multicolumn{4}{c}{ Malaysia } & Indonesia \\
\hline R-squared & 0.447271 & 0.192036 & 0.441217 & 0.395298 & 0.447271 \\
Adjusted R-squared & 0.414757 & 0.144508 & 0.408348 & 0.359727 & 0.414757 \\
S.E. of regression & 284.0814 & 77.72363 & 309.4404 & 103.3172 & 284.0814 \\
Sum squared resid & 2743876. & 205392.7 & 3255614 & 362930.8 & 2743876. \\
Log likelihood & -259.9591 & -212.0033 & -263.1227 & -222.5351 & -259.9591 \\
F-statistic & 13.75648 & 4.040534 & 13.42327 & 11.11302 & 13.75648 \\
Prob(F-statistic) & 0.000042 & 0.026648 & 0.000050 & 0.000193 & 0.000042 \\
\hline \hline
\end{tabular}

Index in Lao PDR positively has causality relationship with Exchange rate in Singapore. Inflation in Singapore positively has causality relationship to Stock price index in Lao PDR. Stock price index in Singapore positively has causality relationship with Inflation in Thailand. Stock price index in Lao PDR positively has causality relationship with Exchange rate in Thailand. Stock price index in Indonesia positively has causality relationship with Stock price index in Lao PDR. Stock price index in Singapore positively has causality relationship with Stock price index in Lao PDR. Stock price index in Indonesia positively has causality relationship with Stock price index in Singapore. R-Square score in Lao PDR is 0.031, it means that the Stock price index has $3.1 \%$ ability to explain Exchange rate and Inflation. This is a weak relationship.

R-Square score in Malaysia is 0.192 , it means that the Stock price index has $19.2 \%$ ability to explain Exchange rate and Inflation. This is a weak relationship. R-Square score in Indonesia is 0.441 , it means that the Stock price index has $44.1 \%$ ability to explain Exchange rate and Inflation. This is a strong relationship. R-Square score in Singapore is 0.395 , it means that the Stock price index has $39.5 \%$ ability to explain Exchange rate and Inflation. This is a weak relationship. R-Square score in Thailand is 0.447 , it means that the Stock price index has $44.7 \%$ ability to explain Exchange rate and Inflation. This is a strong relationship.

\section{CONCLUSION}

In this conclusion we will summarize the relationship between Southeast Asian countries when it is related to their Economic indicator that consists of Stock price index Exchange rate and Inflation. The countries that have causality relationship with internal economic indicators (Domestic indicator) are Malaysia and Singapore. Lao PDR has causality relationship with Economic indicator in Singapore, Malaysia and Indonesia. Malaysia has causality relationship with Economic indicator in Lao PDR and Singapore. Indonesia has causality relationship with Economic indicator in Malaysia. Singapore has causality relationship with Economic indicator in Lao PDR, Malaysia, and Indonesia. Thailand has causality relationship with Economic indicator in Lao PDR and Singapore. In the end considering these five countries in South East Asian they have a causality impact toward each other even if the strength of the relationship is quite weak and in short term in general. This research can be conducted by personal or financial institution to predict short term or 0 to 1 year Economic fluctuation related to Stock price index, Exchange rate and Inflation in Southeast Asian Countries. Future research is expected to involve all the ten countries in ASEAN.

\section{REFERENCES}

Ahmed, A., \& Mubarik, S. 2012. Impact of interest rate and inflation on stock market Index: A case of Pakistan. The Journal of Humanities \& Social Sciences, 20( 2): 1-8.

BI. 2013. Informasi Kurs. Bank Indonesia. URL: http://goo.gl/W6LgHo. Last accessed on 12 August 2015.

Bird, G., \& Rajan, R. 2002. Optimal currency baskets and the third currency phenomenon: Exchange rate policy in Southeast Asia. Journal of International Development, 14(8): 1053-1073. D0I:10.1002/jid.938 
Caputo, R., \& Magendzo, I. 2011. Do exchange rate regimes matter for inflation and exchange rate dynamics? The case of Central America. Journal of Latin American Studies, 43(02): 327-354. D0I:10.1017/S0022216X11000058

Chakravarty, S., \& Mitra, A. 2010. Growth prices and poverty. Journal of Modelling \& Simulation of Systems, 1(4): 235251.

Dimitrova, B.E. 2005. Expertise and explicitation in the translation process. Amsterdam, ND: John Benjamins Publishing. DOI:10.1075/btl.64

Ghozali, I. 2005. Aplikasi analisis multivariate dengan program SPSS. Semarang, ID: Badan Penerbit Universitas Diponegoro . Geiger, T. 2014. Global Competitiveness Report 2014-2015. URL: http://goo.gl/ISna21. Last accessed on 19 April 2016.

Idx. 2004. Indeks. URL: http://goo.gl/sdfr84. Last accessed on 15 December 2015.

Ikoku, A.E., \& Okany, C.T. 2014. Did the Economic and Financial Crises Affect Stock Market Sensitivity to Macroeconomic Risk Factors? Evidence from Nigeria and South Africa. International Journal of Business, 19(3): 275-290.

Ismail, Z., Yahya, A., \& Shabri, A. 2009. Forecasting gold prices using multiple linear regression method. American Journal of Applied Sciences, 6(8): 1509-1514. DOI:10.3844/ajassp.2009.1509.1514

Khalwaty, T. 2000. Inflasi dan solusinya. Jakarta, ID: Penerbit PT Gramedia Pustaka Utama.

Organik, R. 2015. Solusi Tugas Sekolah. URL: http://goo.gl/ak4bTX. Last accessed on 19 April 2016.

Secretariat, A. 2014. Asean member states . URL: http://goo.gl/OtZ9oa. Last acessed on 16 August 2015.

da Silva, F.M., Coronel, D. A., \& Vieira, K. M. 2014. Causality and Cointegration Analysis between Macroeconomic Variables and the Bovespa. PloS One, 9(2): e89765. DOI:10.1371/journal.pone.0089765

Singh, M. 2015. Growth triangles of Southeast Asia: Relevance for peace and stability in ASEAN. International Journal on Arts, Management \& Humanities, 4(1): 61-67.

Taw, N.P. 2015. SAEO Press Release 2015. URL: http://goo.gl/kKxkAq. Last acessed on 17 September 2015.

Wikipedia. 2013. Eviews. URL: https://goo.gl/yzLaEE. Last acessed on 19 April 2016.

— This article does not have any appendix. - 